\title{
PENTINGNYA EVALUASI AFEKTIF PADA PEMBELAJARAN PAI \\ DI SEKOLAH
}

\author{
Betwan \\ Universitas Muhammadiyah Buton \\ betwan.betty646@gmail.com
}

\begin{abstract}
Affective evaluation is one of the evaluation types in PAI learning. However, problems found in the field, that teachers tend to ignore affective evaluation and focus more on learning on cognitive completion alone. So that a gap emerges, the values listed on the student's affective column are not necessarily in accordance with student behavior. So the problem in this study is how to implement affective evaluations of students in Sultan Agung Islamic Junior High School 4 Semarang in PAI learning.

This research is a field research with a qualitative descriptive approach. The subject of this study were the principal, PAI teacher, and students of Sultan Agung Islamic Junior High School 4 Semarang. While the object of research is the affective evaluation of PAI learning with researchers as a key instrument in research. Data in the study were collected using observation and interview techniques to obtain primary data and documentation to obtain secondary data. In the process of collecting data, researchers always make field notes so that the data obtained is not forgotten and can be accurate data. Increasing the persistence of observation, triangulation, and analyzing the negative case, and member check is the technique used to test data credibility. Furthermore, the data are analyzed by steps: analyzing the data that has been collected, conducting data reduction, arranging data, checking the validity of the data, interpreting the data, and concluding the results of the research inductively.

The results showed that the implementation of affective evaluations of students at Sultan Agung Islamic Junior High School 4 Semarang had not been done effectively. This is because the teacher has not prepared a good affective evaluation plan and in its implementation is not yet in accordance with what is stated in the planning. The teacher only uses daily observations and observations without using observation sheets in conducting evaluations.
\end{abstract}

Keywords: Affective Evaluation, PAI Learning

\section{ABSTRAK}

Evaluasi afektif merupakan salah satu jenis evaluasi pada pembelajaran PAI. Namun, masalah yang ditemukan di lapangan, guru-guru cenderung mengabaikan evaluasi afektif dan lebih memfokuskan pembelajaran pada penuntasan kognitif semata. Sehingga muncullah suatu kesenjangan, nilai yang tertera pada kolom afektif siswa belum tentu sesuai dengan perilaku siswa. Sehingga yang menjadi masalah dalam penelitian ini adalah bagaimana pelaksanaan evaluasi afektif siswa di SMP Islam Sultan Agung 4 Semarang dalam pembelajaran PAI.

Penelitian ini tergolong ke dalam jenis penelitian lapangan dengan pendekatan deskriptif kualitatif. Kepala sekolah, guru PAI, dan siswa SMP Islam Sultan Agung 4 Semarang menjadi subjek dalam penelitian. Sedangkan objek penelitian adalah evaluasi afektif pembelajaran PAI dengan peneliti sebagai instrumen kunci dalam penelitian. Data dalam penelitian dikumpulkan 
dengan menggunakan teknik observasi dan wawancara untuk mendapatkan data primer serta dokumentasi untuk mendapatkan data sekunder. Dalam proses pengumpulan data, peneliti selalu membuatkan catatan lapangan agar data yang diperoleh tidak terlupakan dan dapat menjadi data yang akurat. Peningkatan ketekunan pengamatan, triangulasi, analisis kasus negatif, dan member check adalah teknik yang digunakan untuk menguji kredibilitas data. Selanjutnya, data dianalisis dengan langkah-langkah: menelaah data yang berhasil dikumpulkan, mengadakan reduksi data, menyususn data, memeriksa keabsahan data, menafsirkan data, dan menyimpulkan hasil penelitian secara induktif.

Hasil penelitian menunjukan bahwa pelaksanaan evaluasi afektif siswa di SMP Islam Sultan Agung 4 Semarang belum dilakukan dengan efektif. Hal ini dikarenakan guru belum membuat perencenaan evaluasi afektif yang baik dan dalam pelaksanaannya pun belum sesuai dengan yang tertera pada perencanaan yang belum baik tersebut. Guru hanya menggunakan observasi/ pengamatan harian dan pembiasaan tanpa menggunakan lembar pengamatan dalam melakukan evaluasi.

Kata Kunci: EvaluasiAfektif, Pembelajaran PAI 
A. PENDAHULUAN

Pendidikan agama Islam sebagai salah satu mata pelajaran yang mengandung muatan ajaran-ajaran Islam dan tatanan nilai hidup dan kehidupan islami dipandang perlu diarahkan agar guru dapat membekali siswa dengan pengetahuan, pemahaman, penghayatan, dan pengamalan ajaran Islam. Dalam hal ini pembelajaran PAI harus menempatkan ajaran Islam sebagai suatu objek kajian yang melihat Islam sebagai sebuah sistem nilai dan sistem moral yang tidak hanya diketahui dan dipahami, tetapi juga diwujudkan dalam perilaku keseharian di masyarakat. Sebagaimana yang diungkapkan oleh Azra (1999:8-9) bahwa pendidikan agama Islam pada dasarnya memiliki tujuan yang selaras dengan tujuan hidup seorang muslim, yaitu untuk menciptakan pribadipribadi sebagai hamba Allah SWT yang bertakwa dan dapat mencapai kehidupan bahagia di dunia dan akhirat. Sehingga evaluasi pada hasil pembelajarannya bisa dianggap sebagai hal yang krusial dan harus direncanakan dengan matang. Mengingat dalam al-Qur'an juga dijelaskan tentang tujuan hidup seorang muslim ini, yakni dapat dilihat dalam surat Ad Dzariyat: 56, yang artinya "Tidaklah Aku ciptakan jin dan manusia kecuali untuk mengabdi kepadaKu” (Indonesia, 2012: 523).

Pembelajaran adalah kegiatan yang disengaja oleh peserta didik dengan arahan, bimbingan atau bantuan dari pendidik untuk memperoleh suatu perubahan. Perubahan yang diharapkan meliputi: aspek kognitif (pengetahuan), afektif (sikap dan tingkah laku), dan psikomotorik (keterampilan). Perubahan yang diharapkan itu dinamakan dengan kompetensi yang dirumuskan dalam desain pembelajaran. Untuk mengetahui sejauh mana tujuan pembelajaran atau kompetensi yang diharapkan tercapai oleh peserta didik dapat diperoleh melalui evaluasi.

Evaluasi merupakan integral dari pendidikan sehingga perencanaan atau penyusunan, pelaksanaan, dan pendayagunaan pun tidak dapat dipisahkan dari keseluruhan program pendidikan. Evaluasi pembelajaran harus dilakukan pada tiga ranah pendidikan, yakni kognitif, afektif, dan psikomotorik. Ketiga ranah ini saling berkaitan karena apabila salah satunya diabaikan maka akan berakibat tidak baik pada hasil evaluasi pembelajaran yang dilakukan. Jadi, pada dasarnya evaluasi tidak dapat dilakukan hanya pada salah satu ranah pendidikan saja. Akan tetapi, harus seiring dengan dua ranah pendidikan lainnya, afektif dan psikomotorik. Hal ini dianggap perlu karena berangkat dari paradigma evaluasi pendidikan Islam yang menegaskan bahwa ranah kognitif, afektif, dan psikomotorik dilihat secara integral dan saling berkaitan antara satu dengan lainnya. Konsep mengevaluasi dalam pendidikan Islam bersifat menyeluruh, baik dalam hubungan manusia dengan Allah SWT, hubungan manusia dengan manusia, hubungan manusia dengan lingkungan, maupun hubungan manusia dengan dirinya sendiri. Spektrum kajian evaluasi pendidikan Islam pun tidak hanya berkonsentrasi pada ranah kognitif, tetapi juga pada ranah afektif dan psikomotorik. Dalam pembicaraan evaluasi afektif, hal yang harus dilihat tidak hanya pada salah satu aspek, tetapi juga mencakup beberapa aspek lain dalam hubungannya 
dengan pencapaian evaluasi yang baik, mulai dari PAI sebagai mata pelajaran, hasil, hingga evaluasi. Dengan demikian, masalah yang akan dibahas dalam penelitian ini adalah bagaimana pelaksanaan evaluasi afektif siswa di SMP Islam Sultan Agung 4 Semarang dalam mengikuti pembelajaran PAI.

\section{B. KAJIAN PUSTAKA}

Berangkat dari pendapat yang dikemukakan oleh Majid (20I2:I2) bahwa Pendidikan Agama Islam (PAI) merupakan salah satu pelajaran yang diberikan kepada siswa mulai dari tingkat dasar sampai perguruan tinggi yang sarat dengan muatan nilai. Sudah menjadi keharusan jika PAI mendasari pendidikan-pendidikan lain serta menjadi inti untuk masyarakat, orang tua, dan peserta didik. Mata pelajaran PAI sebaiknya memiliki waktu yang proporsional, bukan hanya di madrasah atau sekolah-sekolah yang bernuansa Islam, melainkan juga di sekolah umum. Demikian pula halnya dalam peningkatan mutu pendidikan, PAI sebaiknya menjadi tolok ukur dalam membentuk watak dan kepribadian peserta didik serta membangun moral bangsa (nation character building).

Muhaimin (2003:I4) benambahkan bahwa pendidikan agama Islam bermakna upaya mendidikkan agama Islam atau ajaran Islam dan nilai-nilainya agar menjadi pandangan dan sikap hidup seseorang. Atau kita dapat mengacu ke pendapat Syafaat (2008: II) yang mengatakan bahwa pendidikan agama Islam adalah usaha yang berupa pengajaran, bimbingan, dan asuhan terhadap anak agar kelak selesai pendidikannya dapat memahami, menghayati, dan mengamalkan agama Islam, serta menjadikannya sebagai jalan kehidupan, baik pribadi maupun kehidupan masyarakat. Usaha-usaha tersebut dapat direalisasikan dalam bentuk mata pelajaran yang memenuhi tiga ranah utama dalam PAI. Ranah tersebut adalah kognitif berupa pemahaman atau ilmu yang mencakup syariah, afektif berupa sikap dan perilaku yang mencakup akidah, dan psikomotorik atau keterampilan yang terbentuk karena adanya proses penempaan yang baik dari ranah kognitif dan afektif sehingga menghasilkan suatu keterampilan atau akhlak. Sehingga kehadiran evaluasi dalam pembelajaran PAI sangat diperlukan, terutama evaluasi afektif.

Suharsimi (2003: I78) mengatakan bahwa tujuan dilaksanakannya kegiatan evaluasi afektif secara umum ada dua, yakni: (I) Untuk mengetahui tingkat perubahan tingkah laku siswa yang dicapai antara lain diperlukan sebagai bahan bagi perbaikan tingkah laku siswa, pemberian laporan kepada orang tua dan penentuan lulus tidaknya siswa. (2) Untuk mengukur dan menilai sampai dimanakah efektivitas mengajar dan metode-metode mengajar yang telah disampaikan atau dilaksanakan oleh guru serta kegiatan belajar yang dilaksanakan oleh siswa. Tingkatan ranah afektif terdiri atas lima tingkatan, sebagai berikut.

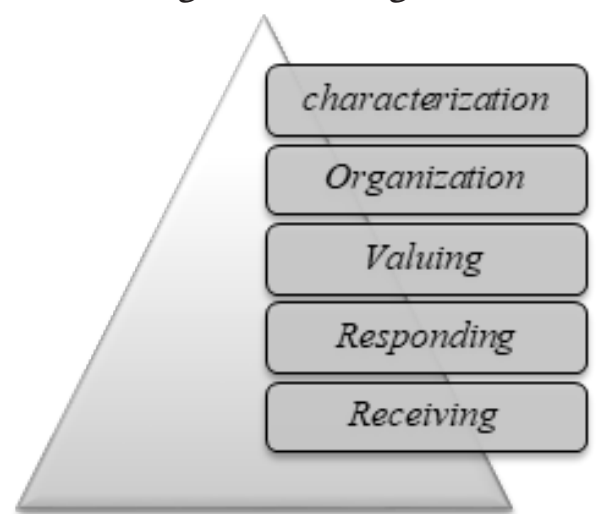


I. Tingkat menerima (receiving), yaitu proses pembentukan sikap dan perilaku dengan cara membangkitkan kesadaran tentang adanya stimulus tertentu yang mengandung estetika. Dalam Sudijono (2013:54) dikatakan bahwa receiving merupakan kemauan untuk memperhatikan suatu obyek. Pada jenjang ini peserta didik dibina agar mereka bersedia menerima nilai yang diajarkan kepada mereka dan mereka mau menggbungkan diri ke dalam nilai itu. Contoh hasil belajar jenjang ini adalah peserta didik wajib menyadari bahwa disiplin wajib ditegakkan, sedangkan sifat malas dan tidak berdisiplin harus ditinggalkan.

2. Tingkat tanggapan (responding), mempunyai beberapa pengertian, antara lain: (I) tanggapan dilihat dari segi pendidikan diartikan sebagai perilaku baru dari siswa sebagai manifestasi dari pendapatnya yang timbul akibat adanya motivasi saat dia belajar; (2) tanggapan dilihat dari segi psikologi perilaku (behaviour psychology) adalah segala perubahan perilaku organisme yang timbul karena adanya rangsangan. Contoh hasil belajar ranah afektif jenjang ini adalah peserta didik bersemangat untuk mempelajari lebih jauh atau menggali lebih dalam lagi tentang ajaran-ajaran kedisiplinan dalam Islam.

3. Tingkat menilai (valuing), dapat diartikan sebagai: (I) pengakuan secara objektif (jujur) bahwa siswa itu objektif, sistem atau benda tertentu mempunyai kadar manfaat; (2) kemauan untuk menerima suatu objek atau kenyataan setelah seseorang itu sadar bahwa objek tersebut mempunyai nilai atau kekuatan, dengan cara menyatakan dalam bentuk sikap atau perilaku positif atau negatif. Contoh hasil belajar afektif jenjang ini adalah tumbuhnya keinginan yang kuat pada diri peserta didik untuk berlaku disiplin, baik di sekolah, di rumah, maupun di tengah-tengah kehidupan masyarakat.

4. Tingkat organisasi (organization), dapat diartikan sebagai: (I) proses konseptualisasi nilai-nilai dan menyusun hubungan antarnilai tersebut, kemudian memilih nilai-nilai terbaik untuk diterapkan; (2) kemungkinan untuk mengorganisasikan nilai-nilai, menentukan hubungan antarnilai, dan menerima bahwa suatu nilai itu lebih dominan dibanding nilai yang lain apabila kepadanya diberikan berbagai nilai.

5. Tingkat karakterisasi (characterization), maksudnya sikap dan perbuatan yang secara konsisten dilakukan oleh seseorang sselaras dengan nilai-nilai yang dapat diterimanya sehingga sikap dan perbuatanya itu telah menjadi ciri-ciri pelakunya. Jenjang ini adalah jenjang afektif paling tinggi karena sikap batin peserta didik benar-benar bijaksana. Sudijono (2013:56) mengatakan bahwa ia telah memiliki philosophy of life yang mapan. Jadi, pada jenjang ini peserta didik telah memiliki sistem nilai yang mengontrol tingkah lakunya untuk suatu waktu yang cukup lama sehingga membentuk karakteristik. Contoh hasil belajar afektif pada jenjang ini adalah peserta didik telah memiliki kebulatan sikap yang diwujudkan dengan menjadikan perintah Allah SWT dalam QS. Al-ashr sebagai pegangan dalam hidupnya terkait dengan kedisiplinan, baik kedisiplinan di sekolah, di rumah, maupun di tengah-tengah masyarakat.

\section{METODE PENELITIAN}

Jenis penelitian ini adalah penelitian lapangan (field research) dengan pendekatan 
penelitian deskriptif-kualitatif, yakni penelitian yang bertujuan menganalisis dan menyajikan fakta secara sistematik tentang kondisi yang terjadi di SMP Sultan Agung 4 Semarang. Dalam pelaksanaannya, peneliti langsung masuk ke lapangan dan berusaha mengumpulkan data secara lengkap sesuai dengan pokok permasalahan yang berhubungan dengan pelaksanaan.

Subjek merupakan orang yang berada pada suatulokasi penelitian guna memberikan informasi kepada peneliti. Saifuddun Azwar (2012: 35) mengatakan bahwa pada dasarnya subjek penelitian itu adalah yang akan dikenai kesimpulan hasil penelitian. Berdasarkan uraian tersebut maka yang menjadi subjek dari judul Evaluasi Afektif pada Pembelajaran PAI di SMP Islam Sultan Agung 4 Semarang adalah: (I) Kepala SMP Islam Sultan Agung 4 Semarang, (2) Guru PAI SMP Islam Sultan Agung 4 Semarang, dan (4) Siswa SMP Islam Sultan Agung 4 Semarang.

Objek penelitian merupakan sifat keadaan "attributes" dari sesuatu benda, orang, atau keadaan yang dijadikan sasaran penelitian. Sifat keadaan yang dimaksud bisa berupa sifat kuantitas dan kualitas (benda, orang, dan lembaga), bisa berupa perilaku, kegiatan, pendapat, pandangan penilaian, sikap pro-kontra atau simpati-antipati, dan keadaan batin. Jadi, yang menjadi objek dalam penelitiaan ini adalah evaluasi afektif pembelajaran PAI di SMP Islam Sultan Agung 4 Semarang. Penelitian ini dilakukan di SMP Islam Sultan Agung 4 Semarang. Untuk memperoleh data primer dalam penelitian ini, digunakan alat pengumpul data berupa observasi dan wawancara, sedangkan dokumentasi berupa arsip yang ada digunakan sebagai data pendukung atau data sekunder. Instrumen-instrumen inilah yang digunakan untuk memperoleh data tentang evaluasi afektif pada pembelajaran PAI di SMP Islam Sultan Agung 4 Semarang.

Observasi, melakukan pengamatan langsung ke lapangan tentang evaluasi afektif pada pembelajaran PAI pada ranah afektif di SMP Islam Sultan Agung 4 Semarang. Termasuk di dalamnya yang diobservasi adalah letak geografis SMP Islam Sultan Agung 4 Semarang, kegiatan pembelajaran dan kegiatan evaluasi afektif, serta programprogram keagamaan di luar kegiatan belajar mengajar. Observasi yang digunakan adalah obeservasi partisipatif. Susan Stainback dalam Sugiyono (2010: 3II) mengatakan bahwa observasi partisipatif adalah peneliti mengamati apa yang dikerjakan orang, mendengar apa yang mereka ucapkan, dan berpatisipasi dalam aktivitas mereka.

Wawancara, Esterberg dalam Sugiyono (2010: 317) mengatakan bahwa wawancara adalah pertemuan dua orang untuk bertukar informasi dan ide melalui tanya jawab sehingga dapat dikontruksikan makna dalam suatu topik tertentu. Wawancara dilakukan langsung dengan siswa, guru PAI, dan kepala sekolah hingga informasi tentang evaluasi afektif di SMP Islam Sultan Agung 4 Semarang dapat terkumpul. Dalam pelaksanaan wawancara, peneliti membawa pedoman berupa garis besar tentang hal-hal yang akan ditanyakan untuk membantu dan mempermudah pencatatan hasil wawancara. 
Dokumentasi, dilakukan untuk memperkuat data yang diperoleh dari wawancara dan observasi yang dilakukan di SMP Islam Sultan Agung 4 Semarang. Dokumen merupakan catatan peristiwa yang sudah berlalu. Sugiyono (2010: 329) mengatakan bahwa dokumen dapat berbentuk tulisan, gambar, atau karyakarya monumental dari seseorang. Dengan dokumentasi, peneliti akan menggali datadata tentang gambaran umum SMP Islam Sultan Agung 4 Semarang, RPP dan Silabus pembelajaran PAI, serta dokumen tentang evaluasi hasil belajar ranah afektif yang digunakan guru.

Keabsahan data dalam penelitian ini dilakukan dengan uji kredibilitas data. Uji kredibilitas data dilakukan dalam bentukpeningkatan ketekunan pengamatan melalui pengamatan secara lebih cermat dan berkesinambungan terhadap subjek penelitian., triangulasi, analisis kasus negatif, dan member check. Analisis data yang dipakai dalam penelitian ini adalah analisis data deskriptif kualitatif. Sesuai dengan penelitian yang bersifat deskriptif, untuk menganalisa data kualitatif digunakan pola piker induktif, yaitu pola berpikir yang berangkat dari faktafakta khusus dan peristiwa konkret kemudian ditarik kesimpulan yang bersifat umum. Jadi, langkah-langkah dalam penelitian ini adalah: (I) Menelaah data yang berhasil dikumpulkan dari hasil observasi, wawancara, dan dokumentasi; (2) Mengadakan reduksi data dengan cara mengambil data yang dapat diolah lebih lanjut; (3) Menyusun data dalam satuan-satuan yang relevan; (4) Melakukan kategorisasi sambil melakukan mengkodean (coding); (5) Mengadakan pemeriksaan keabsahan data; dan

(6) Menafsirkan data dan mengambil kesimpulan secara induktif dengan cara berfikir berdasarkan fakta-fakta khusus untuk diarahkan kepada penarikan kesimpulan yang bersifat umum.

\section{PEMBAHASAN}

I. Pelaksanaan Evaluasi Afektif Siswa di SMP Islam Sultan Agung 4 Semarang

Pelaksanaan evaluasi afektif dilakukan berdasarkan apa yang telah direncanakan sebelumnya. Mengingat evaluasi afektif adalah evaluasi sikap siswa, pelaksanaan evaluasi afektif dapat dilakukan di dalam kelas dan di luar kelas. Pelaksanaan evaluasi afektif di dalam kelas erat kaitannya dengan pembelajaran yang dilakukan oleh guru. Bagaimana guru menyampaikan pelajaran dengan baik dan pembawaan guru serta sikap guru akan menjadi panutan bagi siswa. Sedangkan pelaksanaan evaluasi afektif di luar kelas dapat dilihat dari bagaimana siswa bersikap dan bertingkah laku pada orang lain. Baik di dalam kelas maupun di luar kelas, evaluasi harus dilaksanakan dengan baik, yakni: harus sesuai dengan perencanaan evaluasi afektif, evaluasi harus adil dan objektif, dan adanya pemberian penguatan.

Perencanaan dalam suatu kegiatan dilakukan untuk mengontrol dan memudahkan peneliti dalam melakukan evaluasi. Dengan adanya perencanaan yang baik, evaluasi akan lebih efektif dilakukan. Kesesuaian pelaksanaan evaluasi dengan perencanaan evaluasi afektif maksudnya guru mengevaluasi sesuai dengan apa yang telah direncanakan. Adapun jika tidak sama persis, setidaknya guru tetap dapat mengontrol kegiatan mengevaluasinya, sehingga tidak 
jauh keluar dari jalur evaluasi yang telah ditentukan. Apalagi khusus evaluasi afektif, yang sifatnya tidak sama dengan evaluasi kognitif, kesesuaian pelaksanaan dengan perencanaan evaluasi sangat penting.

Sebagaimana telah disinggung di awal bahwa dalam perencanaan evaluasi afektif di SMP Islam Sultan Agung 4 Semarang guru telah menyampaikan indikator pembelajaran, aspek yang dinilai, teknik dan instrumen evaluasi afektif yang akan digunakan. Dalam pelaksanaannya, instrumen evaluasi afektif yang digunakan belum sesuai dengan instrumen evaluasi yang digunakan untuk melakukan evaluasi afektif, belum menggunakan skala sikap atau lembar pengamatan. Guru hanya menggunaan teknik pengamatan harian dan pembiasaan dapat dijadikan sebagai acuan untuk melakukan evaluasi afektif.

Dari wawancara yang dilakukan dengan dua guru PAI di SMP Islam Sultan Agung 4 Semarang dan dari observasi yang dilakukan peneliti, diketahui bahwa guru tidak melaksanakan penilaian afektif sesuai dengan perencanaan, dalam hal ini tidak sesuai dengan yang tertera pada indikator nilai siswa dalam buku rapor hasil studi yang meliputi indikator sikap (interaktif dengan guru, mengerjakan PR, aktif dalam KBM), minat (kelengkapan catatan, partisipasi aktif, memiliki buku mapel), moral (mengumpulkan tugas tepat waktu, jujur, peduli pada orang lain). Guru belum mengevaluasi afektif siswa dengan mengacu pada rumusan indikator pembelajaran, melainkan evaluasi dilakukan terhadap aspek afektif yang sesuai dengan pengamatan guru selama kegiatan pembelajaran berlangsung.

Hal ini dikarenakan guru merasa telah hafal dengan karakteristik siswa sehingga guru sudah dapat memberikan pertimbangan tersendiri terhadap kompetensi afektif siswa. Selain itu, guru juga belum mendapatkan pembekalan yang spesifik terhadap evaluasi afektif siswa itu sendiri, sehingga tidak ada lembar pengamatan khusus untuk evaluasi afektif. Sedikitnya waktu yang tersedia untuk mengevaluasi menjadi kendala pelaksanaan evaluasi afektif tidak sesuai dengan perencanaan.

Dengan demikian, dapat disimpulkan bahwa dalam pelaksanaan evaluasi afektif siswa pada pembelajaran PAI di SMP Islam Sultan Agung 4 Semarang belum dilakukan sesuai dengan yang tertera pada perencanaan. Walaupun secara eksplisit telah meng-input indikator-indikator karakteristik afektif yang tertera pada format nilai pada kolom afektif siswa, yang meliputi: sikap (interaktif dengan guru, mengerjakan PR, aktif dalam KBM), minat (kelengkapan catatan, partisipasi aktif, memiliki buku mata pelajaran), sedangkan moral (mengumpulkan tugas tepat waktu, jujur, peduli pada orang lain). Akan tetapi, saat pelaksanaan evaluasi tidak sesuai dengan perencanaan maka evaluasi tidak akan menghasilkan efek yang baik dalam perubahan perilaku siswa baik di dalam maupun di luar kelas.

Evaluasi afektif adalah evaluasi pada sikap siswa dalam keseharian. Sikap merupakan hal yang bersifat abstrak, tidak seperti kognitif yang dapat dilihat dari penguasaan materi, sehingga tingkat subjektif dalam 
menilai kemungkinan besar akan susah dihindari. Oleh karena itu, pengusahaan untuk melakukan penilaian secara adil dan objektif sangat dibutuhkan. Kategori adil dan objektif adalah kategori yang relatif, antara siswa yang satu dengan siswa yang lain akan memiliki persepsi yang berbeda perihal keobjektifan guru dalam menilai.

Sesuai hasil wawancara dengan Pak Sodikin, bahwa dalam evaluasi afektif guru selalu bersifat adil. Guru merespon sesuai dengan sikap yang ditampilkan siswa. Guru menegur dan menasihati siswa yang bersalah dan sebaliknya. Guru tidak pilih kasih, tidak membeda-bedakan dalam memperlakukan siswa, akan tetapi seluruh siswa dipandang sama sesuai dengan sikap yang mereka tampilkan. Hal ini sesuai pula dengan pengakuan yang dituturkan oleh salah satu siswa yang peneliti wawancara. Dikatakan bahwa mereka tidak merasa dirugikan dengan nilai yang mereka peroleh, tidak ada diskriminasi, ataupun pilih kasih dari guru.

Wawancara dengan Suwarnoto juga didapatkan bahwa tidak semua siswa yang memiliki nilai baik pada kognitif akan memiliki nilai baik pula pada afektifnya. Ada beberapa siswa yang beliau temui di kelasnya, siswa-siswa tersebut cakap kognitifnya, akan tetapi afektifnya terkesan acuh tak acuh pada mata pelajaran saat di kelas dan tidak menghargai teman saat di luar kelas.

Apabila dilihat dari objektivitas: sikap jujur, tidak dipengaruhi pendapat dan pertimbangan pribadi atau golongan dalam mengambil putusan atau tindakan, evaluasi afektif yang dilakukan oleh guru diSMP Islam
Sultan Agung 4 Semarang belum objektif. Hal ini dikarenakan saat guru mengevaluasi afektif siswa, guru tidak menggunakan lembar pengamatan atau berpedoman pada acuan kriteria afektif yang telah ditetapkan dalam kolom nilai akhir siswa. Evaluasi yang seperti ini tentu akan menghasilkan interpretasi nilai yang tidak konsisten dan dimungkinkan masih dipengaruhi oleh kondisi guru saat memberikan evaluasi.

Jadi, untuk pelaksanaan penilaian yang adil dan objektif tanpa menggunakan lembar pengamatan dan hanya mengandalkan pengamatan harian dan pembiasaan, hasilnya tidak akan seadil dan seobjektif seperti yang diharapkan. Banyak faktor lain yang dapat memengaruhi dalam prosesnya. Salah satunya adalah kondisi psikologi guru. Hasil evaluasi afektif dengan kondisi mood yang baik, hati senang akan berbeda dengan hasil evaluasi yang guru lakukan dalam kondisi emosi yang tidak stabil. Hal inilah yang dapat mengurangi tingkat keakuratan kategori adil dan objektif guru dalam mengevaluasi afektif.

\section{Pemberian Penguatan}

Dalam memberikan penguatan terhadap kemampuan afektif siswa, guru memberikan penguatan dengan menunjukkan mana yang baik dan mana yang kurang baik untuk dilakukan. Hal itu dilakukan dengan menanamkan nilai akidah yang kokoh dalam diri siswa melalui kegiatan keagamaan yang diadakan oleh sekolah. Kegiatan-kegiatan keagamaan yang diadakan secara rutin dapat membiasakan siswa untuk berbuat sesuai dengan apa yang mereka dapatkan dalam kegiatan keagamaan tersebut. Kegiatan 
keagamaan yang dirutinkan di SMP Islam Sultan Agung 4 Semarang adalah shalat dhuha, shalat zuhur berjamaah, tadarus al-Qur'an, menghafal juz 30, dan berdoa sebelum dan setelah belajar.

Guru akan menegur perilaku siswa yang negatif, guru berusaha untuk selalu memberikan contoh yang baik kepada siswa, baik di kelas maupun di luar kelas. Guru selalu mengapresiasi kejujuran siswa dan bagi siswa yang tidak jujur dalam ulangan harian, akan diberi catatan khusus pada kertas ulangan. Guru akan memberi pengurangan nilai pada siswa yang memberi kegaduhan di dalam kelas.

Data tersebut diperkuat oleh hasil observasi yang menunjukan bahwa guru memberikan penguatan terhadap tindakan siswa dengan memberikan pujian dan apresiasi pada siswa yang menampilakan sikap positif dan mengarahkan siswa yang berperilaku menyimpang. Bahkan untuk mengatasi perilaku menyimpang siswa, guru bekerja sama dengan guru Bimbingan Konseling untuk mengarahkan siswa. Siswa selalu diingatkan untuk tenang, dibiasakan untuk menulis dengan rapi, dan mengingatkan siswa untuk selalu jujur. Dengan demikian, dapat disimpulkan bahwa di SMP Islam Sultan Agung 4 Semarang, guru telah memberikan penguatan yang baik untuk menopang afektif siswa. Akan memberikan pujian bagi siswa yang berperilaku positif dan akan mengarahkan siswa yang berperilaku menyimpang selama siswa berada di lingkungan sekolah, baik di dalam maupun di luar kelas.
3. Hasil Evaluasi Afektif Siswa di SMP Islam Sultan Agung 4 Semarang

Mengutip pendapat yang dikemukakan oleh Burhanuddin Tola dalam buku karangan Mulyadi (2010:97) bahwa evaluasi afektif dapat dilakukan dengan beberapa cara atau teknik. Teknik-teknik tersebut antara lain: observasi perilaku, pertanyaan langsung, laporan pribadi, dan penggunaan skala sikap. Guru-guru PAI di SMP Islam Sultan Agung 4 Semarang menggunakan teknik observasi perilaku dalam melaksanakan evaluasi afektif. Observasi perilaku ini dilakukan secara terus menerus hingga afektif siswa benar-benar diketahui. Hal ini dilakukan dengan tidak lari dari ruag lingkup indikator-indikator ketercapaian suatu karakteristik afektif.

Pak Suwarnoto mengaku bahwa dalam melakukan evaluasi afektif, semua indikator tersebut selalu dilihat oleh beliau bahkan semua karakteristik afektif dinilai kemudian nilai positif dan negatif atau sikap yang menonjol dari siswa dicatat dalam buku catatan pribadi. Nilai-nilai ini diperoleh guru tidak serta merta, akan tetapi melalui proses yang panjang. Hingga guru benar-benar tahu dan paham karakter siswa. Nilai-nilai inilah yang nantinya dijadikan pertimbangan dalam menentukan nilai akhir afektif siswa, sehingga pada hasil akhir guru dapat melihat bahwa yang mempunyai kecakapan kognitif yang baik tidak selamanya baik pula dalam hal afektifnya dan sebaliknya, tidak sedikit siswa yang tidak terlalu cakap kognitifnya, tetapi cakap dalam hal afektifnya.

Pak Suwarnoto, salah satu guru PAI, mengatakan bahwa evaluasi afektif beliau 
lakukan kapan dan di mana saja, baik di dalam maupun di luar kelas. Saat beliau punya waktu dan kesempatan untuk melakukan penilaian. Hal ini beliau lakukan mengingat waktu yang dibutuhkan untuk melakukan evaluasi afektif adalah tidak sebentar, lama, hanya saja waktu yang tersedia hanya sedikit. Sementara afektif adalah hal abstrak yang tidak dapat dievaluasi layaknya mengevaluasi kognitif siswa.

Ahmad Rohani dalam sebuah makalahnya yang berjudul Evaluasi Belajar Domain Afektif tepatnya pada halaman 4 mengatakan bahwa tindakan, ucapan, maupun responsi tertulis yang muncul dari siswa itu mencerminkan ciri afektif. Ciri afektif ini dapat ditemukan oleh guru melalui pengamatan yang dilakukan secara terus menerus. Bapak Suwarnoto dalam wawancaranya mengatakan bahwa beliau biasanya melakukan pengamatan langsung dalam mengevaluasi afektif siswanya. Jika pengamatan dilakukan secara terus menerus maka nilai afektif dari siswa dapat ditentukan hanya dalam waktu satu hingga dua bulan. Puncak tertinggi dari afektif adalah internalisasi nilai keagamaan pada siswa sehingga guru dapat mengetahui bahwa terpengaruhkah nilai-nilai keagamaan siswa setelah diajarkan PAI. Mampukah siswa mengubah moral keseharian atau perilaku keseharian berdasarkan nilai-nilai keagamaan dan mampukah siswa mengubah pola pikir mereka berdasarkan nilai-nilai keagamaan.

Setelah guru sudah dapat mengetahui nilai afektif siswa, guru melakukan analisis pada nilai tersebut. Analisis evaluasi afektif dilakukan setelah data dari evaluasi terkumpul. Guru mata pelajaran merumuskan sintesis, sebagai deskripsi dari sikap, perilaku, dan unjuk kerja siswa dalam semester tersebut untuk mata pelajaran yang bersangkutan. Berdasarkan catatan-catatan tentang siswa yang dimiliki guru, guru mata pelajaran dapat memberi masukan pula kepada guru BK untuk merumuskan catatan berupa peringatan atau rekomendasi sebagai bahan bagi wali kelas dalam mengisi kolom deskripsi perilaku dalam rapor. Catatan guru tersebut menggambarkan sikap atau tingkat penguasaan siswa berkaitan dengan mata pelajaran yang ditempuhnya juga perilaku siswa yang perlu mendapat penghargaan/ pujian atau peringatan dalam bentuk kalimat naratif.

Sebagaimana telah dijelaskan dalam bab sebelumnya, bahwa bidang afektif pada dasarnya berkenaan dengan sikap dan nilai. Sikap seseorang dapat diramalkan perubahan-perubahannya bila seseorang telah menguasai bidang kognitif tingkat tinggi. Tipe hasil belajar afektif tampak pada siswa dalam berbagai tingkah laku, seperti atensi (perhatian) terhadap pelajaran, disiplin, motivasi belajar yang tinggi, menghargai guru dan teman sekelas, kebiasaan belajar, dan lain sebagainya. Akan tetapi, hasil belajar bidang afektif kurang mendapatkan perhatian dari guru karena guru lebih banyak memberikan tekanan pada bidang kognitif. Seharusnya, sekalipun mata pelajaran berisi bidang kognitif, bidang afektif harus nampak dalam proses belajar dan hasil belajar yang telah dicapai. Oleh karena itu, guru harus menentukan ranah afektif, selain kognitif dalam pembelajaran agar siswa tidak sekadar memahami dan menghafal materi yang 
diajarkan, tetapi juga mengaplikasikan nilainilai mata pelajaran yang diajarkan.

Evaluasi afektif dalam pembelajaran PAI menjadi sangat penting mengingat tujuan akhir dari pembelajaran PAI adalah bukan hanya menekankan pada penguasaan teori, melainkan juga membina akhlak dan moral siswa dalam kehidupan sehari-hari, baik di lingkungan sekolah maupun di luar sekolah. Sejalan dengan yang dikemukakan oleh Suwarnoto, S.Ag.,M.Hum dalam wawancara yang peneliti lakukan, bahwa Evaluasi afektif di SMP Islam Sultan Agung 4 Semarang adalah dengan merumuskan klasifikasi domain afektif. Sebagaimana telah dirumuskan Bloom dan kawan-kawan meliputi: receiving (menerima), responding (tanggapan), valuing (menilai), organization (organisasi), dan characterization (karakter/ nilai).

Untuk indikator karakteristik yang akan dinilaidiSMPIslamSultanAgung 4Semarang, karakteristik sikap mencakup: responding (keinginan merespon, kepuasan merespon), valuing (menerima suatu nilai, memilih suatu nilai, komitmen atau keterikatan melakukan sesuatu), dan organization (konseptualisasi suatu nilai). Karakteristik minat mencakup: receiving (kesadaran, keinginan untuk menerima, perhatian terkontrol), responding (persetujuan (diam-diam) dalam merespon, keinginan merespon, kepuasan merespon), dan valuing (menerima suatu nilai, menerima suatu nilai). Sedangkan karakteristik moral mencakup: responding (keinginan merespon, kepuasan merespon), valuing (menerima suatu nilai, memilih suatu nilai, komitmen atau keterikatan melakukan sesuatu), dan organization (konseptualisasi suatu nilai). Keseluruhan karakteristik tersebut dievaluasi dengan teknik pengamatan harian dan pembiasaan. Tidak ada lembar pengamatan yang akan menjabarkan satu per satu perihal karakteristik yang telah ditetapkan tersebut, sehingga evaluasi yang digunakan bisa saja tidak menyeluruh.

Siswa dikatakan sukses memiliki kemampuan afektif dalam mata pelajaran PAI apabila dalam belajar siswa tersebut menyenangi dan menyadari tentang pentingnya pendidikan Islam dalam kehidupan, sehingga pada gilirannya menjadikan nilai-nilai yang terkandung dalam mata pelajaran PAI sebagai penuntun hidup. Mengingat dalam evaluasi afektif dilakukan suatu proses, proses yang dimaksudkan di sini adalah penjabaran kurikulum dalam kegiatan belajar mengajar dengan merumuskan tujuan pembelajaran tersebut untuk mencetak siswa yang beriman dan bertakwa kepada Allah SWT dan berakhlakul karimah. Selain itu, tujuan yang diharapkan dari evaluasi afektif ini adalah untuk mengetahui sikap siswa dalam menerapkan akhlak dalam kehidupan (berperilaku) sehari-hari dalam hubungannya dengan Tuhan, hubungannya dengan sesama, dan hubungannya dengan makhluk lainnya.

Evaluasi afektif merupakan usaha untuk mengetahui sejauh mana penguasaan materi PAI dapat dicapai oleh siswa, khususnya terkait dengan sikap dan nilai yang diterapkan oleh siswa sehubungan dengan materi yang ada. Evaluasi afektif dalam pembelajaran PAI adalah proses (kegiatan), sehingga dalam pelaksanaannya tentunya banyak menghadapi kendala dan tantangan. 
Tantangan dan hambatan dalam evaluasi ranah afektif di SMP Islam Sultan Agung 4 Semarang adalah: (I)Waktu; Berbeda dengan evaluasi kognitif yang kerap dilakukan kapan dan dimanapun setelah memberi materi pelajaran kepada siswa untuk mengetahui tingkat pemahaman dan penguasaan siswa terhadap materi pelajaran. Evaluasi afektif tidak dapat dilakukan dengan serta merta setelah penyampaian pokok materi pelajaran dan dapat dilakukan dalam jangka waktu yang relatif pendek. Evaluasi ranah afektif harus dilakukan dalam jangka waktu yang relatif lama, karena yang dievaluasi adalah masalah sikap dan nilai, dan evaluasi tidak hanya dilakukan di kelas, namun juga harus dilakukan di luar sekolah. Hal tersebut juga diakui oleh guru SMP Islam Sultan Agung 4 Semarang bahwa evaluasi ranah afektif membutuhkan waktu yang cukup panjang. Evaluasi sikap ini tidak dapat dilakukan sesaat, karena yang dinilai terkait dengan sikap, yang sewaktu-waktu dapat berubah. (2) Penyusunan instrumen; Kendala yang dihadapi oleh guru adalah penyusunan instrumen penilaian ranah afektif. Berbeda dengan penyusunan instrumen penilaian ranah kognitif, penyusunan instrumen ranah afektif lebih sulit, meskipun secara teoritik banyak para pakar dan ahli pendidikan telah merumuskan beberapa skala pengukuran sikap, namun pengukuran tersebut hanya berlaku untuk pengukuran sikap secara umum.

Kendala-kendala tersebut dalam evaluasi afektif bukan menjadi wacana baru lagi, melainkan telah lama menjadi masalah yang belum mampu diatasi dengan baik. Padahal, evaluasi afektif adalah evaluasi yang tidak dapat dipisahkan dari evaluasi kognitif dan psikomotorik. Seharusnya guru atau pihak yang berwenang mengurusi hal itu segera menyelesaikannya agar tidak menjadi masalah lagi ke depannya dan evaluasi afektif siswa dapat dievaluasi dengan baik; perencanaan dapat disusun dengan baik, pelaksanaan evaluasi dapat disesuaikan dengan perencanaan, serta guru dapat melakukan evaluasi dengan adil dan objektif. Jika evaluasi afektif dilakukan dengan baik, sesuai dengan semua ketentuan di atas maka nilai A pada kolom afektif siswa dalam buku rapor dapat menjadi nilai yang benar-benar A dalam keseharian siswa tersebut.

Dari penjelasan tersebut, dapat disimpulkan bahwa hasil evaluasi afektif di SMP Islam Sultan Agung 4 Semarang belum baik. Hal ini dikarenakan guru hanya menggunakan observasi/pengamatan harian dan pembiasaan tanpa menggunakan lembar pengamatan dalam melakukan evaluasi, sehingga evaluasi yang dilakukan bisa saja tidak menyeluruh. Selain itu, dalam keseharian siswa juga terlihat belum menunjukkan afek yang baik, penanaman nilai untuk mengarah ke tingkat karakterisasi sebagai tingkatan afektif paling tinggi belum dimiliki oleh siswa.

\section{E. PENUTUP}

Berdasar pada analisis yang telah dilakukan, penulis menarik kesimpulan bahwa pelaksanaan evaluasi afektif siswa di SMP Islam Sultan Agung 4 Semarang belum dilakukan dengan efektif. Hal ini dikarenakan:

I. Guru belum membuat perencenaan evaluasi afektif yang baik dan dalam pelaksanaannya 
pun belum sesuai dengan yang tertera pada perencanaan yang belum baik tersebut.

2. Guru hanya menggunakan observasi/ pengamatan harian dan pembiasaan tanpa menggunakan lembar pengamatan dalam melakukan evaluasi, sehingga evaluasi yang dilakukan bisa saja tidak menyeluruh.

3. Dalam keseharian siswa juga terlihat belum menunjukkan afek yang baik, penanaman nilai untuk mengarah ke tingkat karakterisasi sebagai tingkatan afektif paling tinggi

\section{DAFTAR PUSTAKA}

Ahid, Nur. (2010). Pendidikan Keluarga dalam Prespektif Islam. Yogyakarta: Pustaka Belajar.

Amenah. (20I4). Evaluasi Proses dan Produk pada Pembelajaran PAI di SMA Negeri I3 Semarang. Tesis Magister, Tidak Diterbitkan, IAIN Walisongo, Semarang.

Andayani, Dian dan Abdul Majid. (2004). Pendidikan Agama Islam Berbasis Kompetensi. Bandung: Remaja Rosdakarya. Arifin, Zainal. (20II). Penelitian Pendidikan (Metode dan Paradigma Baru). Bandung: PT Remaja Rosdakarya.

Arikunto, Suharsimi. (I989). Dasar-Dasar

Evaluasi Pendidikan. Cet. V. Jakarta: Bina Aksara.

Evaluasi Pendidikan. Jakarta: PT Remaja Rosdakarya.

Aziz, Abdul. (2010). Orientasi Pendidikan Agama di Sekolah. Yogyakarta: Teras.

Azwar, Saifuddin. (1989). Sikap Manusia; Teori dan Pengukurannya. Yogyakarta: Liberty.

Psikologi. Cet. XIV. Yogyakarta: Pustaka Pelajar.
Bakri, Ihsan Bakri. (20I4). Pengembangan Evaluasi Afektif dalam Proses Pembelajaran Pendidikan Agama Islam (Studi Kasus Pengembangan Instrumen Penilaian Sikap dan Minat Siswa dalam Proses Pembelajaran PAI di SMA Negeri IO Semarang. Tesis Magister, Tidak Diterbitkan, Unissula, Semarang.

Bukhari, Umar. (2010). Ilmu Pendidikan Islam. Jakarta: Amzah.

Darajat, Zakia. (20I2). Ilmu Pendidikan Islam. Jakarta: Bumi Aksara.

Daulay, Haidar Putra.(2012). Pendidikan Islam dalam Menceradaskan Bangsa. Jakarta: Rineka Cipta. -(20I4). Pendidikan Islam dalam Prespektif Filsafat. Jakarta: Kencana.

Departemen Pendidikan dan Kebudayaan. (2003). Undang-Undang RI Nomor 20 Tahun 2003 Tentang Sistem Pendidikan Nasional. Jakarta: Pusat Data dan Informasi Pendidikan, Balitbang Depdiknas.

Fahmi, Burhanuddin Tola. (2003). Standar Penilaian di Kelas. Jakarta: Departemen Agama Republik Indonesia.

Hajaroh, Mami. (2004). Pengembangan Evaluasi Afektif Mata Kuliah Pengembangan Kepribadian (MPK) pada D-II PGSD Guru Kelas Universitas Negeri Yogyakarta. http://staff.uny.ac.id/sites/default/files/ mami\%20hajaroh/artikel\%20evaluasi\%20 afektif.pdf; diakses tanggal I8 Agustus 2015. Hasan, Said Hamid.(2009). Evaluasi Kurikulum.

Bandung: PT Remaja Rosdakarya.

Hawi, Akmal. (2013). Kompetensi Guru PAI. Bandung: Rajawali Press.

Hayati, Mimin. (2007). Model dan Teknik Penilaian pada Tingkat Pendidikan. Jakarta: Gaung Persada Pres. 
HM, Ahmad Rohani. (2004). Struktur Afektif; Suatu Pemahaman Terhadap Konsep Krathwol. Et A1.I964. Makalah disajikan dalam Lokakarya Pengembangan Sistem Penilaian Hasil Belajar Non-Kognitif, Diselenggarakan Oleh Lembaga Kajian Pendidikan Keislaman dan Sosial (Lekdis) Nusantara Bekerjasama dengan Direktorat Mapenda Depag RI, Tanggal 29 September s.d. 02 Oktober 2004 di Asrama Haji Balikpapan Kalimantan Tengah.

Kementerian Agama Republik Indonesia. (2012). Al-Qur'an dan Terjemahannya. Jakarta: CV Media Fitra Rabani.

Kunandar. (2007). Guru Profesional dan Grafindo Persada.

Majid, Abdul. (2012). Belajar dan Pembelajaran Pendidikan Agama Islam. Bandung: PT Remaja Rosdakarya.

Mas'ud, Abdurrahman. (2004). Antologi Agama dan Pendidikan. Semarang: Aneka Ilmu.

MKDP, T. P. (20I2). Kurikulum dan Pembelajaran. Jakarta: Rajawali Pers.

Muchsin, Bashori M. S. (2010). Pendidikan Islam humanistik: Alternatif Pendidikan Pembebasan Anak. Bandung: Refika Aditama.

Muhaimin. (2003). Wacana Pengembangan Pendidikan Islam. Yogyakarta: Pustaka Pelajar.

------------. (2004). Paradigma Pendidikan Islam: Upaya Mengefekttifkan Pendidikan Islam di Sekolah. Bandung: PT Remaja Rosdakarya.

Mulyadi. (2010). Evaluasi Pendidikan: Pengembangan Model Evaluasi Pendidikan Agama di Sekolah. Malang: UIN Maliki Press. Implementasi KTSP. Jakarta: PT Raja

Jakarta: kencana.

Peraturan Menteri Pendidikan Nasional Nomor 20 Tahun 2007 tentang Standar Penilaian Pendidikan. Jakarta: Direktoral Jenderal Manajemen Pendidikan Dasar dan Menengah.

Priyanto, Edi. (20I4). Implementasi Penilaian Afektif PAI di MAN Kota Kediri 3. Tesis Magister, Tidak Diterbitkan, STAIN Kediri, Kediri.

Rahman, Abdul. (20I2). Pendidikan Islam dan Pendidikan Agama Islam: Tinjauan Epistemologi dan Isi Materi.Eksis Vol. 8 No. I, 2055.

Ramayulis. (2013). Ilmu Pendidikan Islam. Jakarta: Kalam Mulia.

Satmoko, Retno Sriningsih. (I999). Proses Belajar Mengajar II: Penilaian Hasil Belajar. Semarang: IKIP Semarang Press.

Shaleh. (2005). Pendidikan Agama dan Pembangunan Watak Bangsa. Jakarta: PT Raja Grafindo Persada.

Soetopo, Hendyat. (2007). Evaluasi Program Supervisi Pendidikan. Malang: Proyek EPF IKIP Malang.

Sudijono, Anas. (2006). Pengantar Statistik

Pendidikan. Jakarta: PT Raja Grafindo Persada.

Sugiyono. (2004). Metode Penelitian Kuantitatif dan Kualitatif dengan R \& D. Bandung: Alfabeta.

(2010). Metode Penelitian

Pendidikan (Pendekatan Kuantitatif, Kualitatif, dan R \& E). Bandung: Alfabeta. Syafaat, Aat. (2008). Peranan Pendidikan Agama Islam. Jakarta: PT Raja Grafindo Persada. Tashakkori, Abbas, dan Charles Teddlie. (2010). Handbooks of Mixed Methods in Social and Behavioral research. Jakarta: Pustaka Pelajar. Nata, Abuddin. (2010). Ilmu Pendidikan Islam. Qomari, Rohmad. (2009). Pengembangan 
Instrumen Domain Afektif. Insania Vol. I3

No. I. https://insaniaku.files.wordpress.

com/2009/03/7-pengembanganinstrumen-evaluasi-domain-afektif-rohmadqomari.pdf; diakses tanggal 5 April 2015.

Yusanto, M. Ismail. (2014). Menggagas

Pendidikan Islam. Bogor: Al Azhar Press. 